\title{
Prevalence and Molecular detection of some virulence genes among Salmonella species Isolated from Poultry
}

\section{Mahmoud Ezzat ${ }^{1}$, Mahmoud Elsotohy ${ }^{2}$, Abo Elkheir Esawy ${ }^{2}$, Ali Wahdan ${ }^{1}$}

${ }^{1}$ Department of Bacteriology, Immunology and Mycology, Faculty of Veterinary Medicine, Suez Canal University, 41522 Ismailia, Egypt. ${ }^{2}$ Animal Health Research Institute, Bacteriology, Immunology and Mycology department, Mansoura laboratory, Egypt.

* Mahmoud Ezzat.... Email: mezzat05@yahoo.com * Mahmoud Elsotohy.... Email: medo_sotohy2005@yahoo.com

* Abo Elkheir Esawy.... Email: esawy55@gmail.com * Ali Wahdan.... Email: dr_aly_w@yahoo.com

\begin{abstract}
:
The current study aimed to isolate the salmonella species from different organs of broilers with complete phenotypic identification of the recovered isolates. After that all recovered isolates were tested for detection of some genes responsible for pathogencity. A total of 250 samples from broilers farms were examined bacteriologically for isolation of salmonella. All recovered isolates were identified phenotypically, biochemically and serologically. PCR technique was used for detection of invA, hilA and avrA genes. Bacteriological examination of samples revealed that Salmonella was recovered in 34 samples out of 250 samples (13.6\%). Twelve $S$. Typhimurium, $8 S$. Kentucky, $5 S$. Newport, 2 $S$. Tamale, $2 S$. Enteritidis, $1 S$. Molade, $2 S$. Takoradi, $1 S$. Virchow and $1 \mathrm{~S}$. Inganda were isolated from broilers with percentage of (35.29\%), (23.5\%), (14.7\%), (5.88\%), (5.88\%), (2.94\%), (5.88\%), $(2.94 \%)$ and $(2.94 \%)$ respectively. All tested Salmonella serovars showed positive amplification at $284 \mathrm{bp}, 150 \mathrm{bp}$ and $422 \mathrm{bp}$ fragments which specific for the invA gene (common gene), hilA gene and avrA gene respectively, with total percentage (100\%) from examined samples.
\end{abstract}

Keywords: Salmonella species, Salmonella virulence genes, broilers, PCR.

\section{Introduction:}

Salmonellosis is an important health problem and a major challenge worldwide. Salmonella spp. are Gram negative and rod shape which have been divided into over 2700 serotypes based on somatic, flagellar and capsular antigens (Gallegos et al., 2008). Many authors (Bailey and Maurer, 2001; 
Mølbak et al., 2006) have outlined that bacteria of genus Salmonella are important causes of foodborne infections in humans, and the most frequent etiological bacterial agents of foodborne disease outbreaks. Inparticular, two Salmonella serotypes, $S$. Enteritidis and $S$. Typhimurium became major causes of human illness in the 1980s and 1990s, with important impact on public health and the economy in industrialized countries.

The genus Salmonella is divided into two species Salmonella Enterica and Salmonella Bongori; Salmonella Enterica itself is comprised of 6 subspecies. They are $S$. Enterica subsp. Enterica, $S$. Arizonae, $S$. Diarizonae, $S$. Indica, $S$. Salamae \& S. Houtenae or I, II, IIIa,IIIb, IV and VI, respectively (Popoff and Minor, 1997; Brenner, et al., 2000).

Salmonella pathogenicity island (SPI) is a genetic element that occurs as a distinct and separate unit in the bacterial chromosome. There are approximately 200 genes including those on the five Salmonella chromosomal pathogenicity islands (SPI-1 to SPI5) on Salmonella chromosomes that are essential for their virulence Hensel (2004).

To fulfill the aim of the work, the following were done:

1- Isolation of Salmonella using global standard methods (from internal organs) in different poultry farms.
2- Identification of the isolated organism (biochemical and serological identification).

3- Detection of common Salmonella virulence genes using cPCR.

\section{Material and methods:}

Samples: A total of 250 chicken samples from broilers farms were collected for Salmonella isolation and these samples include liver, caecum, spleen and heart blood. All samples were put in sterile plastic bags in ice box and transported directly to Mansoura laboratory (Animal Health Research Institute).

Identification of the isolates: Each sample was inoculated separately in selenite $\mathrm{F}$ broth and incubated at $37^{\circ} \mathrm{C}$ for not more than 18 hours and rappaport-vassiliadis soya broth incubated at $42^{\circ} \mathrm{C}$ for 24 hours. A loopful from the enrichment culture was streaked onto the surface of Xylose Lysine Deoxycholate (XLD), Salmonella Shigella agar (S-S agar) and MacConkey's plates then incubated at $37^{\circ} \mathrm{C} \pm 1^{\circ} \mathrm{C}$ for $24 \mathrm{hrs} \pm 2 \mathrm{hrs}$. MacConkey's plates were used to detect the presence of coliform lactose fermenters. Each colony was identified morphologically and biochemically according to Quinn et al. (2002).

\section{Serological identification:}

The preliminarily identified isolates biochemically as Salmonella were subjected to serological identification according to Kauffman-White Scheme (Kauffman, 1974) for 
determination of somatic $(\mathrm{O})$ and flagellar $(\mathrm{H})$ antigens using slide agglutination test.

PCR detection of Salmonella isolates virulence genes: Ten Salmonella serovars were examined for detection of invA, hilA and avrA genes. QIAamp DNA Mini Kit used for extraction of DNA. Primers used were shown in table (2). Temperature and time conditions of the primers during PCR are shown in table (3). Electrophoresis grade agarose $(1 \mathrm{~g})$ was prepared in $100 \mathrm{ml}$ TBE buffer in a sterile flask, it was heated in microwave to dissolve all granules with agitation, and allowed to cool at $70^{\circ} \mathrm{C}$, then $0.5 \mu \mathrm{g} / \mathrm{ml}$ ethedium bromide was added and mixed thoroughly according to (Sambrook et al., 1989)

\section{Results:}

A total of 250 chickens (70apparently healthy, 90 diseased chickens and 90 freshly dead broiler chickens) were collected from different farms in Dakahlia Governorate and the clinically examined birds showed signs of septicemia, retarded growth, depression, profuse watery white diarrhea and accumulation of fecal matter around the vent. While the freshly dead birds show bronze discoloration and enlargement of liver, spleenomegaly, inflammation of intestine and caecum and unabsorbed yolk sacs in young chicks. Bacteriological examination of samples all over seasons of the year revealed that salmonella was recovered in 34 samples with an incidence rate $13.6 \%$ (34 out of 250). It was clear that Salmonella was recovered from 4 samples out of 70 examined samples from apparently healthy chicken (5.7\%), 18 samples out of 90 diseased chickens (20\%) and 12 samples out of 90 freshly dead broiler chickens $(13.33 \%)$ were found to be positive for Salmonella as shown in table (1).After culturing on XLD, Salmonella appeared as smooth red coloured colonies with black center. While on Hektone enteric it appeared as deep blue colonies but on MacConkey's agar appeared as pale, colorless smooth, transparent and raised colonies and on Salmonella Shigella (S-S) agar Salmonella produce colourless colonies with black centers due to $\mathrm{H} 2 \mathrm{~S}$ production. The staining characters appeared as Gram negative, non-spore forming short rod shaped. Serologically identified into twelve $S$. Typhimurium, $8 S$. Kentucky, $5 S$. Newport, $2 S$. Tamale, $2 S$. Enteritidis, $1 S$. Molade, $2 S$. Takoradi, $1 S$. Virchow and $1 S$. Inganda were isolated from broilers with percentage of (35.29\%), (23.5\%), (14.7\%), (5.88\%), (5.88\%), (2.94\%), $(5.88 \%), \quad(2.94 \%)$ and $(2.94 \%)$ respectively.

All 10 Salmonella serovars showed positive amplification at $284 \mathrm{bp}$, $150 \mathrm{bp}$ and $422 \mathrm{bp}$ fragments which specific for the invA gene (common gene), hilA gene and avrA gene 
respectively, with total percentage in figure 1,2 and 3 .

$(100 \%)$ from examined samples as

Table (1) Incidence of Salmonella infection in examined chickens

\begin{tabular}{|l|c|c|c|}
\hline \multicolumn{1}{|c|}{ Examined chicken } & $\begin{array}{c}\text { Number of } \\
\text { examined chicken }\end{array}$ & $\begin{array}{c}\text { Number of } \\
\text { positive }\end{array}$ & $\boldsymbol{\%}$ \\
\hline Apparently healthy chicken & 70 & 4 & 5.7 \\
\hline Diseased chicken & 90 & 18 & 20 \\
\hline Freshly dead chicken & 90 & 12 & 13.33 \\
\hline Total & 250 & 34 & 13.6 \\
\hline
\end{tabular}

Table (2): Primers of some virulence genes.

\begin{tabular}{|c|c|c|c|}
\hline Primer & Sequence $(5-3)$ & $\begin{array}{c}\text { Amplified } \\
\text { product (size) }\end{array}$ & Reference \\
\hline \multirow{2}{*}{$\operatorname{inv} \mathrm{A}$} & GTGAAATTATCGCCACGTTCGGGCAA & \multirow{2}{*}{$284 \mathrm{bp}$} & \multirow{2}{*}{$\begin{array}{c}\text { Oliveira } e t \\
\text { al., } 2003\end{array}$} \\
\hline & TCATCGCACCGTCAAAGGAACC & & \\
\hline \multirow{2}{*}{ Hila } & CATGGCTGGTCAGTTGGAG & \multirow{2}{*}{$150 \mathrm{bp}$} & \multirow{2}{*}{$\begin{array}{c}\text { Yang et al., } \\
2014\end{array}$} \\
\hline & CGTAATTCATCGCCTAAACG & & \\
\hline \multirow{2}{*}{$\operatorname{avrA}$} & CCT GTA TTG TTG AGC GTC TGG & \multirow{2}{*}{$422 \mathrm{bp}$} & \multirow{2}{*}{$\begin{array}{c}\text { Huehn et al. } \\
2010\end{array}$} \\
\hline & AGA AGA GCT TCG TTG AAT GTC C & & \\
\hline
\end{tabular}

Table (3): Cycling conditions of the different primers during $c P C R$

\begin{tabular}{|c|c|c|c|c|c|c|}
\hline Gene & $\begin{array}{c}\text { Primary } \\
\text { denaturation }\end{array}$ & $\begin{array}{c}\text { Secondary } \\
\text { denaturation }\end{array}$ & $\begin{array}{c}\text { Anneali } \\
\text { ng }\end{array}$ & Extension & $\begin{array}{l}\text { No. of } \\
\text { cycles }\end{array}$ & $\begin{array}{c}\text { Final } \\
\text { extension }\end{array}$ \\
\hline $\operatorname{inv} \mathrm{A}$ & $\begin{array}{l}94^{\circ} \mathrm{C} \\
5 \mathrm{~min} .\end{array}$ & $\begin{array}{c}94^{\circ} \mathrm{C} \\
30 \mathrm{sec} .\end{array}$ & $\begin{array}{c}55^{\circ} \mathrm{C} \\
30 \mathrm{sec}\end{array}$ & $\begin{array}{l}72^{\circ} \mathrm{C} \\
30 \mathrm{sec}\end{array}$ & 35 & $\begin{array}{l}72^{\circ} \mathrm{C} \\
7 \mathrm{~min} .\end{array}$ \\
\hline hila & $\begin{array}{l}94^{\circ} \mathrm{C} \\
5 \mathrm{~min} .\end{array}$ & $\begin{array}{c}94^{\circ} \mathrm{C} \\
30 \mathrm{sec} .\end{array}$ & $\begin{array}{c}60^{\circ} \mathrm{C} \\
30 \mathrm{sec}\end{array}$ & $\begin{array}{l}72^{\circ} \mathrm{C} \\
30 \mathrm{sec}\end{array}$ & 35 & $\begin{array}{l}72^{\circ} \mathrm{C} \\
7 \mathrm{~min} .\end{array}$ \\
\hline$a v r \mathrm{~A}$ & $\begin{array}{r}94^{\circ} \mathrm{C} \\
5 \mathrm{~min} .\end{array}$ & $\begin{array}{r}94^{\circ} \mathrm{C} \\
30 \mathrm{sec} .\end{array}$ & $\begin{array}{r}58^{\circ} \mathrm{C} \\
30 \mathrm{sec} .\end{array}$ & $\begin{array}{r}72^{\circ} \mathrm{C} \\
30 \mathrm{sec} .\end{array}$ & 35 & $\begin{array}{c}72^{\circ} \mathrm{C} \\
10 \mathrm{~min} .\end{array}$ \\
\hline
\end{tabular}

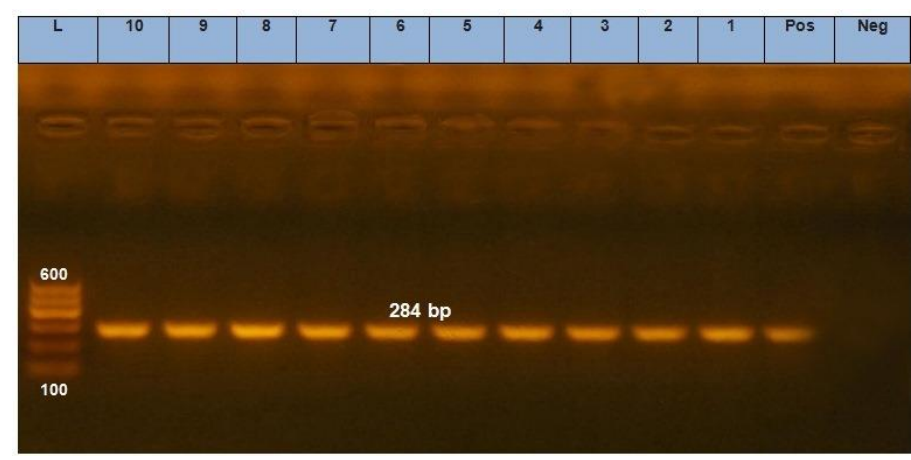

Figure (1): PCR photo showing Salmonella invA gene at 284 bp. Lane L: 100-600pb DNA ladder. Pos.: Positive control (reference strain from Animal 
Health Research Institute, Dokki, Egypt). Neg.: Negative control. Lane 1: $S$. Kentucky. Lane 2: $S$ Tamale. Lane 3: $S$. Inganda. Lane 4 and 7: $S$. Typhimurium. Lane 5: $S$. Newport. Lane 6: $S$. Molade. Lane 8: $S$. Enteritidis. Lane 9: $S$. Takoradi. Lane 10: $S$. Virchow.

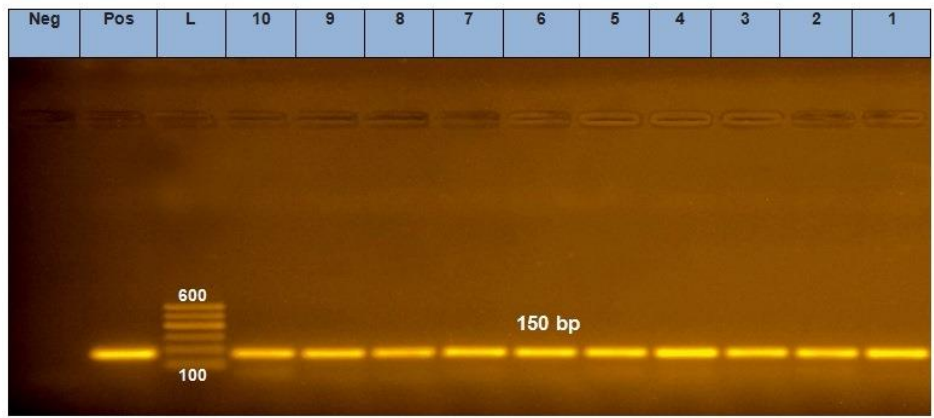

Figure (2): PCR photo showing Salmonella hilA gene at $150 \mathrm{bp}$. Lane L: 100-600pb DNA ladder, Pos.: Positive control (reference strain from Animal Health Research Institute, Dokki, Egypt). Neg.: Negative control. Lane 1: $S$. Kentucky. Lane 2: $S$ Tamale. Lane 3: $S$. Inganda. Lane 4 and 7: $S$. Typhimurium. Lane 5: $S$. Newport. Lane 6: $S$. Molade. Lane 8: $S$. Enteritidis. Lane 9: S. Takoradi. Lane 10: $S$. Virchow.

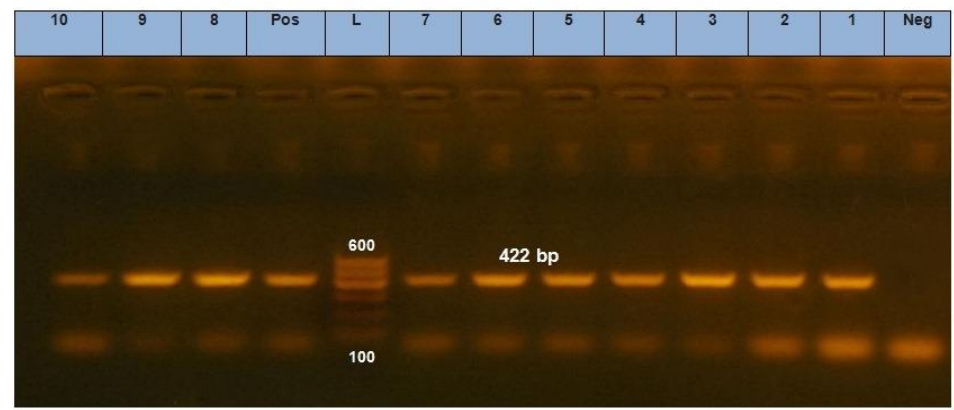

Figure (3): PCR photo showing Salmonella avrA gene at 422 bp. Lane L: 100-600pb DNA ladder. Positive control (reference strain from Animal Health Research Institute, Dokki, Egypt). Neg.: Negative control. Lane 1: $S$. Kentucky. Lane 2: $S$ Tamale. Lane 3: $S$. Inganda. Lane 4 and 7: $S$. Typhimurium. Lane 5: $S$. Newport. Lane 6: $S$. Molade. Lane 8: $S$. Enteritidis. Lane 9: $S$. Takoradi. Lane 10: $S$. Virchow.

\section{Discussion:}

In this study 250 broiler chickens from different poultry farms in Dakahlia governorate were examined for the presence of Salmonella, 34 out of 250 chickens
(13.6\%) were found positive while $216(86.4 \%)$ chickens were negative for Salmonella isolation. The incidence of Salmonella in broilers was $13.6 \%$ (34 out of 250 chickens) and these results agree with 
Rehan (2004) who isolated Salmonella species from broiler chickens with an incidence of $12 \%$, Ammar et al. (2010) who identified the most common Salmonella serovars in broilers and laying breeding reproducers in Eastern Algeria and isolated $S$. Typhimurium with incidence of (12\%). Chon et al. (2015) investigated the occurrence of Salmonella spp. isolated from 120 chicken carcasses produced in 6 poultry slaughterhouses in South Korea were 11 samples (9.2\%). Osman (1992) isolated 45 Salmonella strains with an incidence of $30 \%$ out of 150 random samples from different broiler farms. On the other hand, lower incidence was recorded by Magwedere et al. (2015) was 5\%. Ibrahim et al. (2018) discussed that the prevalence of Salmonella was $6.8 \%$ in broilers, $42.3 \%$ in layers, $0 \%$ in breeders and cloacal swabs, $6.5 \%$ in litter and $15.6 \%$ in eggs.

In this study Salmonella were rapidly detected by targeting invA gene, giving PCR product of $284 \mathrm{bp}$ size. Therefore, this technique can be used for the screening of Salmonella in the routine testing. Darwin and Miller (1999) reported that the invA gene encodes a protein in the inner membrane of bacteria, which is necessary for invasion to the epithelial cells of the host. Lampelet al. (2000) observed that Salmonella specific PCR with primers for invA is rapid, sensitive, and specific for detection of
Salmonella in many clinical samples. The genes hilA, hilC, hilD and $i n v \mathrm{~F}$ suggests that these regulators operate in a hierarchy to modulate invasion gene expression with hilA acting as the central regulator in this cascade. The hilA, is required for expression of SPI-1 invasion genes (Schechter and Lee, 2000). The inv $\mathrm{F}$ and its putative chaperone protein, sicA (along with hilA) is responsible for activating and controlling the expression of TTS-associated proteins encoded within and outside of SPI-1.

PCR assay was carried out for the detection of the avrA gene from isolated strains has revealed that the gene was present in all of the isolates $(100 \%)$ which was demonstrated by the presence of a 422 bp PCR product. The results obtained in the present study were in corroboration with Karen et al., (2013); Ren et al., (2016). Moreover, Claudete et al. (2017) detected the avrA gene in all of the $S$. Pullorum and $S$. Gallinarum serotype strains $(100 \%)$ and 38 (97.4\%) strains of the paratyphoid group were positive. avrA is an effector protein of the TTSS complex that contributes to the virulence of Salmonella spp. by limiting the host's inflammatory responses through the inducement of cell apoptosis, especially of macrophages, and by the innibition of IL-8 and TNF- $\alpha$ (CollierHyamset al., 2002).

\section{Conclusion:}


From the previous result, concluded that widespread of Salmonella spp. among the broilers in Dakahlia Governorate in this study may be due to insufficient hygiene, improper disinfection in hatcheries and farms. Also, there are defect in farm biosecurity. Further studies are needed to improve surveillance strategies to decrease the prevalence of Salmonella spp. in chicken population of Dakahlia Governorate. PCR technique is rapid and a sensitive confirmatory method detection of Salmonella.

\section{References:}

Ammar, A.; Alloui, N. ; Bennoune, O. and KassahLaouar, A. (2010): Survey of Salmonella serovars in broilers and laying breeding reproducers in East of Algeria. Journal Infection Dev Ctries. 4(2):103-106.

Bailey, J.S. and Maurer, J.J. (2001): Salmonella Species. In: Food Microbiology: Fundamentals and Frontiers, 2nd en, eds Doyle, M. P., L. R. Beuchat \& T. J. Montville, ASM Press, Washington D.C., pp. 141-178.

Brenner, F.W.; Villar, R.G.; Angulo, F.J.; Tauxe, and Swaminathan, B. (2000): Salmonella nomenclature, Journalof Clinical Microbiology, vol. 38, no. 7, pp. 2465-2467.

Chon, J. W.; Jung, H. I.; Kuk M.; Kim, Y. J.; Seo, K. H. and Kim, S. K.(2015): High occurrence of extended-spectrum $\quad \beta$-lactamase- producing Salmonella in broiler carcasses from poultry slaughterhouses in South Korea.Foodborne Pathog Dis.;12(3):190-6.

Claudete, S. Astolfi-Ferreira; Marcelo, R.S. Pequini; Luis, F. N. Nuñez; Silvana, H. Santander Parra; Ruy, Chacon; David, I. D. de la Torre; Antonio, C. Pedroso and Antonio, J. Piantino, Ferreira (2017): A comparative survey between non-systemic Salmonella spp.(paratyphoid group) and systemic Salmonella Pullorum and S. Gallinarum with a focus on virulence genes. Pesq. Vet. Bras. 37(10):1064-1068.

Collier-Hyames, L.S.; Zeng, H.; Sun, J.; Tomlinson, A.D.; Bao, Z.Q.; Chen, H.; Madara, J.L.; Orth, K.; Chen, H. and Neish, A.S. (2002): Cutting edge: Salmonella avrA effector inhibits the key proinflammatory, antiapoptotic NF-kB pathway. J. Immunol. 169:2846-2850.

Darwin, K.H. and Miller, V.L. (1999): Molecular basis of the interaction of Salmonella with the intestinal mucosa. Clin. Microbiol. Rev. 12:405-428.

Gallegos, R.; Loredo, A.; Ojeda, G. and Vega, A. (2008): Identification of Salmonella serotypes isolated from cantaloupe and chile pepper production system in Mexico using PCR-RFLP. J. Food Protect., 71(11): 2217-2222.

Hensel, M. (2004): Evolution of pathogenicity islands of Salmonella 
enterica. Int. J. Med. Microbiol. 294: 95-102.

Huehn, S.; La Ragione, R.M.;Anjum, M.;Saunders, M.;Woodward,

C.;Helmuth,

E.;Guerra,

J.;Brisabois,

T.;Svensson,

M.J.;Bunge, R.;Hauser,

B.;Beutlich, A.;Peters, G.;Litrup, E;Imre, A.HerreraLeon, S.;Mevius, D.;Newell, D.G. andMalorny B. (2010): Virulotyping and antimicrobial resistance typing of Salmonella enterica serovars relevant to human health in Europe. Foodborne Pathogens Dis 2010; 7:523-35.

Ibrahim, Madiha, Salah; Wael, Said, El Shafey; Mohammed, Farouq, Hashim and Ahmed, Abo-Elmagd, Bekheet (2018):Detection of salmonella serovars and their common virulence genes from different chicken breeding systems.ejpmr, (7), 54-60.

Karen, A. Borges; Thales, Q. Furian; Anderlise. Borsoi; Hamilton, L.S. Moraes; Carlos, T.P. Salle and Vladimir, $P$. Nascimento(2013):Detection of virulence-associated genes in Salmonella Enteritidis isolates from chicken in South of Brazil.Pesq. Vet. Bras. vol.33 no.12.

Kauffman, F. (1974): Serological diagnosis of Salmonella species. Kauffman white scheme Minkagaord, Copenhagen, denmark.
Lampel, K.A.; P.A. Orlandi and L. Kornegay, (2000): Improved template preparation for PCR-based assay for detection of food-borne bacterial pathogens. Appl. Environ. Microbiol., 66: 4539-4542.

Magwedere, K.; Rauff, D.; De Klerk, G.; Keddy, K. H. and Dziva, F. (2015):Incidence of Non typhoidal Salmonella in FoodProducing Animals, Animal Feed, and the Associated Environment in South Africa, 2012-2014.Clin Infect Dis. 1;61 Suppl 4:S283-9. doi: 10.1093/cid/civ663.

Mølbak, K.; J. E. Olsen and H. C. Wegener (2006): Salmonella infections. In: Foodborne Infections and Intoxications, 3rd edn, eds Riemann, H. P. \& D. O. Cliver, Academic Press, pp. 57-136.

Oliveira, S.D.; Rodenbusch, C.R.; Cé, M.C.; Rocha, S.L. and Canal, C.W. (2003): Evaluation of selective and non-selective enrichment PCR procedures for Salmonella detection. Lett Appl Microbiol. 36(4):217-221.

Osman, M.M. (1992): Studies on bacterial causes of early poultry mortality in Sharkia Governorate. M.V.Sc. Thesis (Bacteriology) Fac. Vet. Med. Zagazig Univ

Popoff, M.Y. and Le Minor, L.(2001): Antigenic formulas of the Salmonella serovars, 8th revision. Paris: World Health Organization Collaborating Centre for Reference and Research on Salmonella, Pasteur Institute, 2001. 
Quinn, P.J.; B.K. Markey; M.E. Carter; W.J. Donnelly and F.C. Leonard (2002): Veterinary Microbiology and Microbial Diseases. 1st Edn., WileyBlackwell Science, USA., 544-549.

Rehan, H. M. (2004): Application of PCR for identification of salmonellae in chicken Thesis; M. Sc.; (Bacteriology, Mycology \& Immunology), Mansoura University, Fac.Vet. Med library.

Ren, X.; Li, M.; Xu, C.; Cui, K.; Feng, Z.; Fu, Y.; Zhang, J. and Liao, M. (2016): Prevalence and molecular characterization of Salmonella enterica isolates throughout an integrated broiler supply chain in China. Epidemiol Infect.;144(14):2989-2999.

Sambrook, J.; Fritscgh, E.F. and Mentiates (1989): Molecular coloning. A laboratory manual. Vol. I, Cold spring Harbor Laboratotry press, New York.

Schechter, L.M. and Lee, C.A. (2000): Salmonella invasion of nonphagocytic cells. In Subcellular Biochemistry, Oelschlaeger, T., and Hacker, J. (eds). New York: Kluwer Academic/Plenum Publishers.

33:289-320

Yang, X.; Brisbin, J.; Yu, H.; Wang, Q.; Yin, F.; Zhang, Y.; Sabour, P.; Sharif, S. and Gong, J. (2014). Selected Lactic AcidProducing Bacterial Isolates with the Capacity to Reduce Salmonella Translocation and Virulence Gene Expression in Chickens. PLOS ONE | www.plosone.org 1 April 2014 | Volume 9 | Issue 4 | e93022.

$$
\begin{aligned}
& \text { مدى تواجد والكشف الجزيئي لبعض جينات الضراوة بين أنواع السالمونيلا المعزولة من الدواجن }
\end{aligned}
$$

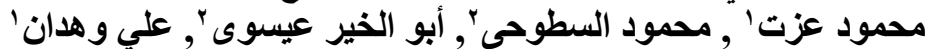

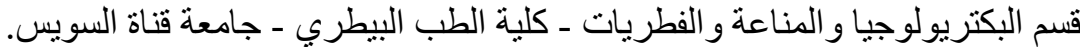

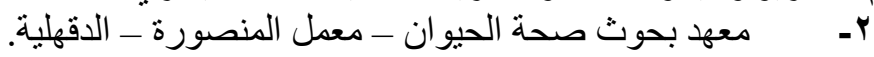

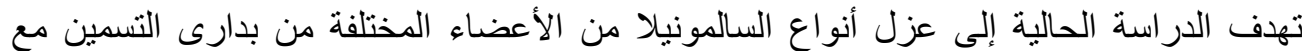

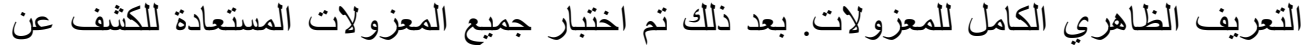

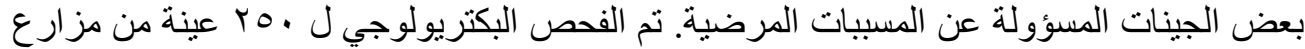

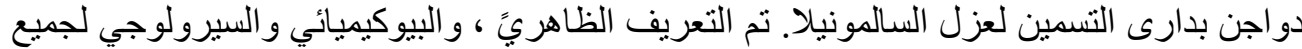

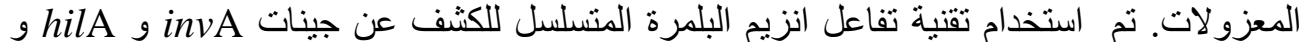
بvrA (T,7 ( T)

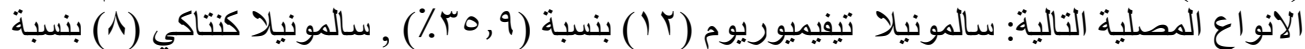
(Y,0)

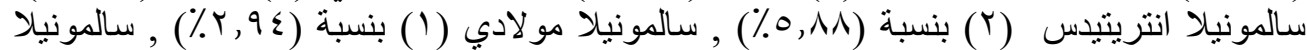

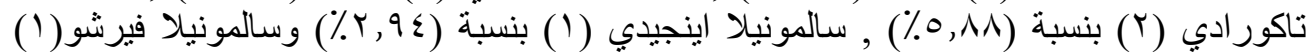

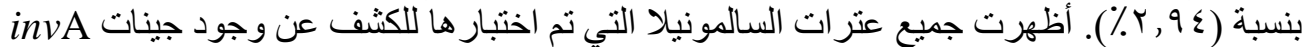

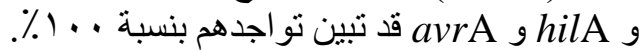

